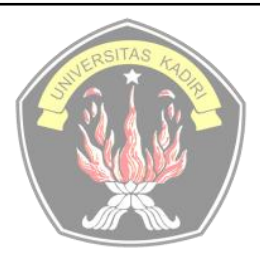

Tersedia online di

\title{
Mediasi Burnout Pada Pengaruh Ambiguitas Dan Konflik Terhadap Komitmen Pegawai Manufaktur Di Bantul
}

Choirunnisak $^{1}$, Ignatius Soni Kurniawan ${ }^{2}$

1,2, Program Studi Manajemen, Universitas Sarjanawiyata Tamansiswa, Yogyakarta email: soni_kurniawan@ustjogja.ac.id

\section{Artikel History:}

Artikel masuk : 04-12-2019

Artikel revisi : 30-03-2020

Artikel diterima : 05-04-2020

\section{Keywords:}

ambiguitas peran, konflik peran, burnout, komitmen.

\begin{tabular}{l}
\hline ABSTRAK \\
\hline Penelitian ini bertujuan untuk menguji pengaruh ambiguitas peran \\
dan konflik peran terhadap komitmen pegawai dengan burnout \\
sebagai variabel pemediasi. Sampel penelitian adalah 120 pegawai \\
pada empat perusahaan manufaktur yang berlokasi di Bantul \\
Yogyakarta. Temuan riset menyatakan bahwa burnout memediasi \\
pengaruh ambiguitas dan konflik peran terhadap komitmen. \\
Penelitian menghasilkan temuan menarik yaitu ambiguitas peran \\
berpengaruh negatif terhadap burnout dan konflik peran \\
berpengaruh positif terhadap komitmen.
\end{tabular}

\section{ABSTRACT}

This study aims to examine the effect of role ambiguity and role conflict on employee commitment with burnout as a mediating variable. The research sample was 120 employees of four manufacturing companies located in Bantul, Yogyakarta. Research findings suggest that burnout mediates the influence of ambiguity and role conflict on commitment. The study produced an interesting finding that role ambiguity had a negative effect on burnout and role conflict had a positive effect on commitment.

\section{PENDAHULUAN}

Sumber daya manusia memainkan peran kunci dalam menentukan kelangsungan hidup, efektivitas, dan daya saing bisnis (Zeng et al., 2011). Peningkatan kualitas sumber daya di perusahaan membutuhkan peran dari organisasi itu sendiri, hal ini diperkenalkan oleh Kahn et.al.,(1964) dengan nama teori dinamika peran organisasi. Organisasi mendorong kualitas 

demikian terdapat fenomena dimana pegawai justru mengalami konflik peran, ambiguitas peran, dan burnout yang dapat mempengaruhi komitmen kerjanya. Lee \& Ashforth (1996) menyatakan bahwa burnout terjadi ketika seseorang tidak bisa memenuhi permintaan, atau tidak menghasilkan sesuatu, karena beberapa faktor tuntutan pekerjaan termasuk ambiguitas peran, konflik peran, stress, beban kerja yang berat dan tekanan. Faktor organisasi diidentifikasi sebagai penyebab yang berkontribusi pada proses burnout termasuk peran ambiguitas dan konflik peran (Lloyd, King, \& Chenoweth, 2002).

Peran didefinisikan sebagai pola perilaku, ambiguitas peran mengacu pada harapan seputar peran, dan konflik peran melibatkan ketidakcocokan tuntutan yang dihadapi individu (Ilgen \& Hollenbeck, 1991). Ambiguitas peran terjadi ketika individu karyawan tidak jelas mengenai perintah atau tugas tertentu atau dalam istilah yang lebih umum tidak tahu apa yang seharusnya dilakukan (Harms \& Luthans, 2012). Konflik peran adalah salah satu dari beberapa kondisi yang dianggap menyebabkan masalah dalam sistem sosial termasuk ambiguitas peran, diskontinuitas peran dan peran yang berlebihan (ketika orang dihadapkan dengan harapan terlalu banyak) (Biddle, 1986). Singh (2000), Lloyd et al. (2002), dan Yener, Oskaybas, \& Dursun (2014) menyatakan bahwa ambiguitas peran berpengaruh positif terhadap burnout. Leiter \& Maslach (1988) menemukan bahwa konflik peran dan hubungan dengan supervisor yang tidak menyenangkan berpengaruh positif terhadap burnout. Salehi \& Gholtash (2011) menyatakan bahwa job burnout memiliki efek negatif terhadap komitmen organisasi.

Mengadopsi dari penelitian yang dilakukan oleh Singh (2000), penelitian ini melakukan pengujian kembali dengan meletakan variabel burnout sebagai variabel pemediasi antara ambiguitas dan konflik peran terhadap komitmen khususnya pada pegawai perusahaan manufaktur di Bantul. Intersender sebagai role stressor (stres peran) dan variabel komitmen sebagai job outcomes (hasil pekerjaan) pegawai. Penelitian ini diharapkan dapat menemukan perbedaan hasil dalam memprediksi pengaruh secara langsung maupun tidak langsung antara stress peran dan hasil pekerjaan.

\section{TINJAUAN PUSTAKA}

Harms \& Luthans (2012) menjelaskan komitmen organisasi sebagai keinginan kuat karyawan untuk tetap menjadi anggota organisasi, kesediaan untuk mengerahkan segala energi yang dimiliki untuk organisasi, dan sesuai dengan tujuan organisasi. Porter, Steers, \& Boulian (1973) menjelaskan bahwa komitmen dapat ditandai oleh setidaknya tiga faktor: 1) keyakinan yang kuat dan penerimaan terhadap tujuan dan nilai organisasi, 2) kesediaan untuk Mediasi Burnout Pada Pengaruh.... 
mengerahkan upaya yang cukup besar atas nama organisasi, 3) dan keinginan yang pasti untuk mempertahankan keanggotaan organisasi. Meskipun komitmen penting untuk menjaga kinerja pegawai, namun dalam penelitian (Kurniawan \& Tamrin, 2019) afektif komitmen tidak menjadi penyebab turnover intention. Indikator komitmen organisasi menurut Buchanan (1974) yaitu: identifikasi organisasional, keterlibatan, dan kesetiaan (loyalitas).

Burnout adalah fenomena yang biasa digunakan untuk menggambarkan keadaan atau proses kelelahan (Neckel, Schaffner, \& Wagner, 2017). Istilah burnout menurut Kim \& Stoner (2008) diperkenalkan untuk merujuk pada fenomena yang diamati di antara individu yang pekerjaannya berurusan melayani orang lain dan bekerja dengan orang banyak yang dituntut secara emosional. Burnout mencakup kelelahan kognitif, afeksi, dan konatif, yang dapat menurunkan produktivitas kerja. Indikator burnout dalam penelitian Singh (2000) meliputi burnout pada manajemen dan pelanggan.

Ambiguitas menurut Rizzo, House, \& Lirtzman (1970) dan Harms \& Luthans (2012) terjadi ketika karyawan tidak paham atas tugas yang diberikan oleh organisasi. Johnson \& Stinson (1975) membagi dimensi ambiguitas menjadi dua yaitu 1) ambiguitas tugas (task ambiguity) dengan mengukur sejauh mana seseorang memahami tugas pekerjaan mereka, tanggung jawab, dan wewenang dengan jelas; 2) umpan balik ambiguitas (feedback ambiguty) adalah item yang mengukur sejauh mana seseorang menyadari langsung evaluasi dari atasan pada pekerjaan mereka.

Harms \& Luthans (2012) menyebutkan bahwa konflik peran terjadi ketika karyawan atau anggota tim diminta untuk melakukan tugas yang saling bertentangan, dengan nilai-nilai pribadi individu. Pada kegiatan kerja yang membutuhkan kerjasama kelompok, peluang konflik biasanya akan meningkat, terutama ketika kelompok terlibat dalam perilaku tidak etis atau antisosial dan ketika anggota kelompok menekankan satu set norma sementara pemimpin dan aturan dari organisasi formal menekankan yang lain. Johnson \& Stinson (1975) menyebutkan dimensi konflik peran dibagi menjadi dua yaitu intersender dan person-role. Intersender yaitu skala konflik peran yang memuat item-item yang mengukur sejauh mana seseorang menerima permintaan yang tidak sesuai mengenai pekerjaan mereka, sedangkan hal-hal yang termasuk dalam skala konflik person-role diukur sejauh mana pekerjaan seseorang menuntut tugas yang mereka rasa seharusnya tidak menjadi bagian dari pekerjaan mereka (Johnson \& Stinson, 1975). Indikator untuk mengukur konflik peran, yaitu intersender dan resource/demands (Singh, 2000). 


\section{Pengembangan Hipotesis}

Lee \& Ashforth (1996) menyatakan bahwa burnout terjadi ketika seseorang tidak bisa memenuhi permintaan, atau tidak menghasilkan sesuatu karena beberapa faktor tuntutan pekerjaan termasuk ambiguitas peran, konflik peran, stress, beban kerja yang berat dan tekanan. Lloyd et al. (2002) menyatakan bahwa faktor organisasi diidentifikasi sebagai penyebab yang berkontribusi pada proses burnout termasuk peran ambiguitas dan konflik peran. Maslach, Schaufeli, \& Leiter (2001) mengatakan bahwa konflik peran dan ambiguitas peran secara konsisten menunjukkan korelasi sedang hingga tinggi terhadap penyebab burnout. Singh (2000) menyatakan bahwa ambiguitas peran berpengaruh positif terhadap burnout. Yener et al. (2014) mempelajari faktor-faktor yang menyebabkan karyawan mengalami burnout, hasilnya menunjukkan bahwa keadilan organisasi, ambiguitas peran, konflik peran, dan sinisme adalah alasan utama terjadinya burnout dalam organisasi, dan dampak masalah paling penting yang dihadapi karyawan sebagai akibat dari burnout adalah penurunan kepuasan kerja, dan komitmen organisasi.

H1: Ambiguitas peran berpengaruh positif terhadap burnout.

H2: Konflik peran berpengaruh positif terhadap burnout.

Salehi \& Gholtash (2011) menyatakan bahwa job burnout memiliki efek negatif terhadap komitmen organisasi. Dijelaskan jika seseorang individu bekerja dengan baik dan melakukannya lebih dari sekedar penjelasan tugas, maka prinsip ini mengasumsikan bahwa individu tersebut memiliki komitmen emosional atau memiliki ketergantungan yang tinggi terhadap organisasi. Babakus, Cravens, Johnston, \& Moncrief (1999) menyatakan kelelahan emosional dalam dimensi burnout berpengaruh negatif terhadap komitmen organisasional. Singh (2000) menyatakan bahwa burnout berpengaruh negatif terhadap komitmen, burnout mengarah pada berkurangnya komitmen organisasi.

H3: Burnout berpengaruh negatif terhadap komitmen.

Menurut Porter et al. (1973) komitmen dapat ditandai oleh setidaknya tiga faktor: keyakinan yang kuat dalam penerimaan terhadap tujuan dan nilai organisasi, kesediaan untuk mengerahkan upaya yang cukup besar atas nama organisasi, dan keinginan yang pasti untuk mempertahankan keanggotaan organisasi. Fisher \& Gitelson (1983) menyimpulkan bahwa ambiguitas peran terkait positif dengan tingkat pendidikan, dan berhubungan negatif dengan komitmen organisasi, keterlibatan pekerjaan, kepuasan dengan rekan kerja dan promosi, rentang batas, masa kerja, dan usia, sedangkan konflik peran tidak terkait dengan kinerja tetapi berhubungan negatif dengan komitmen, keterlibatan, kepuasan dengan gaji, rekan kerja, pengawasan, dan partisipasi dalam pengambilan keputusan. 
Hasil penelitian Han, Han, An, \& Lim (2014) menunjukkan bahwa ambiguitas peran mengurangi komitmen organisasi. Di sisi lain konflik peran dan ambiguitas peran meningkatkan tingkat kejenuhan serta memiliki efek tidak langsung pada komitmen organisasi dan kelelahan. Judeh (2011) dalam temuannya melaporkan bahwa ambiguitas peran dan konflik peran muncul sebagai mediator signifikan dari hubungan antara sosialisasi karyawan dan komitmen organisasi.

H4: Ambiguitas peran berpengaruh negatif terhadap komitmen.

H5: Konflik peran berpengaruh negatif terhadap Komitmen.

Han, Han, An, \& Lim (2014) menempatkan burnout sebagai variabel pemediasi pada stress role ambiguity dan stress role conflict terhadap turnover sebagai job outcomes, hasilnya adalah burnout memainkan peran penting dalam hubungan stress role ambiguity dan stress role conflict. Han, Han, An, \& Lim (2014) merekomendasikan mengembangkan rencana untuk meningkatkan komitmen organisasi karena memediasi rolestress dan intensi turnover sebagai job outcomes. Singh (2000) meletakkan burnout sebagai variabel mediasi dari pengaruh stres peran terhadap hasil pekerjaan. Penelitian Singh (2000) membahas tentang ambiguitas peran perusahaan dan konflik peran intersender sebagai stres peran dan variabel komitmen sebagai hasil pekerjaan, di mana stress peran sebagai antasedan dan hasil pekerjaaan sebagai konsekuensinya. Hasil penelitian Singh (2000) membuktikan bahwa variabel burnout mampu memisahkan aspek fungsional (eustress) dan disfungsional (distrees) dari role stressor terhadap hasil pekerjaan (job outcomes) sehingga melalui aspek role sressor dan burnout dapat dilakukan tindakan perbaikan.

H6: Burnout memediasi pengaruh ambiguitas peran terhadap komitmen.

H7: Burnout memediasi pengaruh konflik peran terhadap komitmen.

\section{METODE PENELITIAN}

Penelitian ini menggunakan metode kuantitatif dan metode pengumpulan data menggunakan kuesioner dengan 5 skala likert. Indikator komitmen diambil dari Buchanan (1974), ambiguitas peran, konflik peran dan burnout diambil dari Singh (2000). Populasi penelitian adalah pegawai 4 manufaktur yang berlokasi di Bantul (PT Adi Satria Abadi, PT Bintang Alam Semesta, PT Hari Mukti Teknik, PT Ide Studio) dengan teknik pengambilan sampel accidental sampling. Karena keterbatasan akses informasi jumlah pegawai tidak diketahui secara pasti maka pengambilan sampel menggunakan rumus Formula Lemeshow (Ogston, Lemeshow, Hosmer, Klar, \& Lwanga, 1991) sebagai berikut ini: 
$\mathrm{n}=\frac{Z a^{2} X P X Q}{L^{2}}$

$\mathrm{n}=\frac{1.96^{2} \times 0.5 \times 0.5}{(0.1)^{2}}=96.04$

n : Jumlah sampel yang diperlukan;

Za : Nilai standar dari distribusi sesuai nilai $\alpha=5 \%=1.96$;

P : Prevalansi outcome, karena data belum didapat, maka dipakai 50\%;

Q : : 1-P;

L : Tingkat Ketelitian $10 \%$.

Penelitian ini menggunakan 120 responden yang telah memenuhi batas minimal 96 responden.

\section{HASIL \& PEMBAHASAN}

Item dinyatakan valid apabila nilai $r_{\text {hitung }}>r_{\text {tabel }}(0.1478)$. Item corrected item-total correlation menghasilkan $r_{\text {hitung }}$ variabel ambiguitas peran $(0.306-0.582)$, konflik peran $(0.198$ $-0.471)$, burnout $(0.390-0.727)$, dan variabel komitmen $(0.289-0.532)>0.1478$. Cronbach's alpha based on standardized items ambiguitas peran sebesar 0.723, konflik peran 0.614, burnout 0.764 , dan komitmen $0.698>0.6$ atau reliabel.

Tabel 1. Karakteristik Responden

\begin{tabular}{lll}
\hline Karakteristik & Keterangan & $\%$ \\
\hline Jenis & Laki-Laki & 89.2 \\
Kelamin & Perempuan & 10.8 \\
\hline \multirow{3}{*}{ Usia } & 17-24 tahun & 11.7 \\
& 25-34 tahun & 38.3 \\
& 35-49 tahun & 39.2 \\
& 50-64 tahun & 10.8 \\
\hline \multirow{3}{*}{ Pendidikan } & SD/Sederajat & 11.7 \\
Terakhir & SLTP/Sederajat & 21.7 \\
& SLTA/sederajat & 58.3 \\
& S1 & 8.3 \\
\hline
\end{tabular}

Karakteristik responden (Tabel 1) menunjukkan lebih banyak reponden laki-laki (89.2\%) yang menunjukkan bahwa pekerjaan lebih banyak membutuhkan kekuatan fisik. Usia responden terbanyak pada rentang 35-49 tahun (39.2\%) menunjukkan kebanyakan pekerja berada pada usia yang matang yang mewakili ketercukupan keterampilan dan pengalaman. Mayoritas responden adalah lulusan SLTA/sederajat (58.3\%) yang menunjukkan kewajaran pendidikan yang umumnya dipersyaratkan untuk pekerja di lantai operasi manufaktur.

Tabel 2 menunjukkan tidak ada mulitikolonieritas pada model regresi I dan II dengan nilai tolerance $>0.10$ dan VIF $<10$. Heteroskedastisitas juga tidak terjadi pada kedua model 
regresi yang ditunjukkan dengan nilai t park test yang memiliki $p>0.05$ atau tidak signifikan.

Data residual pada kedua model regresi juga terdistribusi normal yang ditunjukkan dengan nilai Kolmogorov-Smirnov Z yang memiliki asymp.sig (2 tailed) > 0.05 atau tidak signifikan.

Tabel 2. Asumsi Klasik

\begin{tabular}{|c|c|c|c|c|c|c|c|c|}
\hline \multirow[t]{2}{*}{ Model } & \multirow[t]{2}{*}{ Independent } & \multirow[t]{2}{*}{ Dependent } & \multicolumn{2}{|c|}{ Multicollinearity } & \multicolumn{2}{|c|}{ Park Test } & \multicolumn{2}{|c|}{$\begin{array}{l}\text { Kolomogrov- } \\
\text { Smirnov Test }\end{array}$} \\
\hline & & & Toll. & VIF & $t$ & $p$ & $K-S Z$ & Asymp.Sig \\
\hline \multirow{2}{*}{$I$} & Ambiguitas & & .452 & 2.214 & -1.446 & .151 & \multirow{2}{*}{1.105} & \multirow{2}{*}{.174} \\
\hline & Konflik & Burnout & .452 & 2.214 & .745 & .458 & & \\
\hline \multirow{3}{*}{ II } & Burnout & & .898 & 1.113 & .696 & .488 & \multirow{3}{*}{1.917} & \multirow{3}{*}{.114} \\
\hline & Ambiguitas & Komitmen & .407 & 2.457 & -1.517 & .132 & & \\
\hline & Konflik & & .434 & 2.306 & -.252 & .802 & & \\
\hline
\end{tabular}

Tabel 3 menunjukkan nilai t dari ambiguitas peran (-2.202) terhadap burnout adalah negatif, dengan demikian $\mathrm{H} 1$ yang menyatakan ambiguitas peran berpengaruh positif terhadap burnout ditolak. Nilai t dari konflik peran terhadap burnout (3.582) memiliki nilai $p / 2=0.000<$ 0.05 dengan demikian $\mathrm{H} 2$ yang menyatakan konflik peran berpengaruh positif terhadap burnout diterima

\section{Tabel 3 Hasil Uji Regresi}

\begin{tabular}{|c|c|c|c|c|c|c|c|}
\hline \multirow[b]{2}{*}{ Independent } & \multirow[b]{2}{*}{ Dependent } & \multicolumn{2}{|c|}{ Unstd. Coeff. } & \multirow{2}{*}{$\begin{array}{c}\text { Std. } \\
C . \\
\text { Beta }\end{array}$} & \multirow[t]{2}{*}{$t$} & \multirow[t]{2}{*}{ Sig. } & \multirow{2}{*}{$\begin{array}{c}A d j \\
R^{2}\end{array}$} \\
\hline & & $B$ & Std. E. & & & & \\
\hline (Constant) & & 9.211 & 1.046 & & 8.807 & .000 & \\
\hline Ambiguitas & Burnout & -.128 & .058 & -.287 & -2.202 & .030 & .003 \\
\hline Konflik & & .212 & .059 & .467 & 3.582 & .000 & \\
\hline (Constant) & & 25.410 & 1.472 & & $\begin{array}{r}17.25 \\
9\end{array}$ & .000 & \\
\hline Burnout & Komitmen & -.296 & .101 & -.266 & -2.931 & .004 & .118 \\
\hline Ambiguitas & & -.205 & .065 & -.415 & -3.173 & .002 & \\
\hline Konflik & & .269 & .068 & .534 & 3.955 & .000 & \\
\hline
\end{tabular}

Tabel 3 menunjukkan nilai $\mathrm{t}$ dari burnout $(-2.931)$ memiliki nilai $p / 2=0.002<0.05$, ambiguitas peran $(-3.173)$ memiliki sig. $p / 2=0.001<0.05$ artinya H3, H4 diterima. Konflik peran memiliki nilai t 3.955, nilainya positif dengan demikian H5 yang menyatakan konflik peran berpengaruh negatif terhadap komitmen ditolak.

Hasil perhitungan Sobel test pada Gambar 2 menunjukkan nilai two-tailed probability sebesar $0.049<0.05$, sehingga H6 yang menyatakan burnout memediasi pengaruh ambiguitas peran terhadap komitmen, diterima. 


\section{Gambar 1. Uji Mediasi Hipotesis 6}

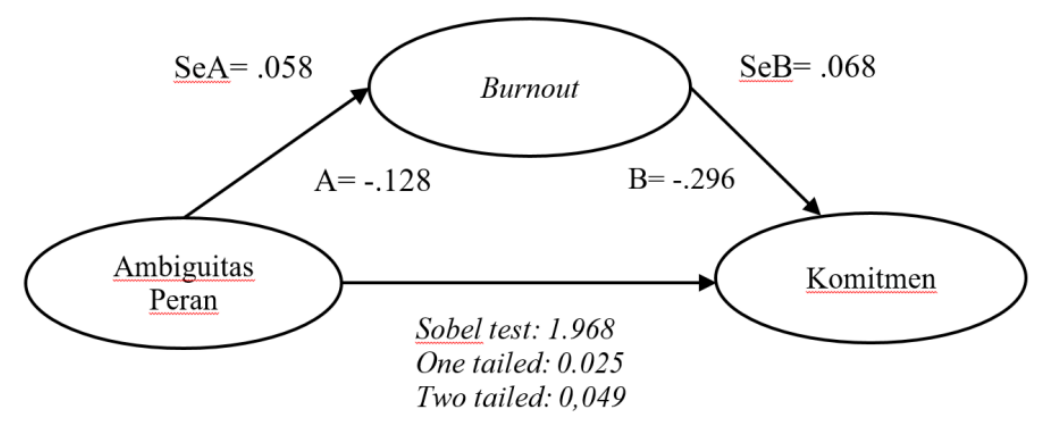

Hasil perhitungan uji sobel pada Gambar 2 menunjukkan nilai two-tailed probability sebesar $0.006<0.05$ sehingga $\mathrm{H} 7$ yang menyatakan burnout memediasi pengaruh konflik peran terhadap komitmen, diterima.

Gambar 2. Uji Mediasi Hipotesis 7

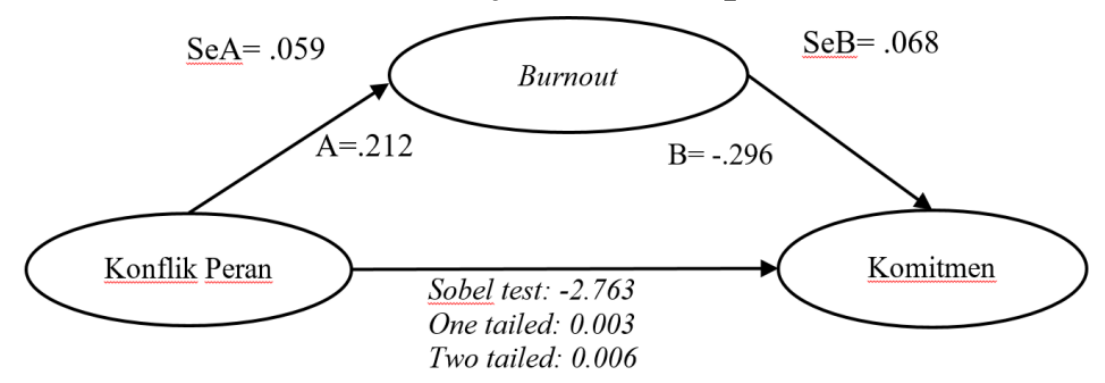

\section{Pembahasan}

Hipotesis 1 yang memberikan dugaan pengaruh positif ditolak, hasil uji justru menunjukkan ambiguitas peran berpengaruh negatif signifikan terhadap burnout. Hal ini diduga karena sebanyak 50\% responden berusia diatas 35 tahun yang menunjukkan pengalaman kerja yang cukup untuk menghadapi ambiguitas peran justru hal untuk meningkatkan diri sehingga permasalahan ditanggapi dengan positif yang menurunkan burnout. Temuan pengaruh negatif ambiguitas peran terhadap burnout ini mengkonfirmasi hasil riset Zhaleh, Ghonsooly, \& Pishghadam (2018). Namun demikian tidak otomatis disarankan bagi pimpinan perusahaan untuk meningkatkan ambiguitas karena dalam penelitian lain ambiguitas dalam pekerjaan ditemukan berpengaruh positif terhadap burnout dan berpengaruh negatif terhadap kinerja ( $\mathrm{Wu}$, $\mathrm{Hu}$, \& Zheng, 2019).

Pengujian hipotesis kedua menunjukkan bahwa konflik peran berpengaruh positif terhadap burnout, temuan ini mengkonfirmasi penelitian Lee \& Ashforth (1996); Fogarty, Singh, Rhoads, \& Moore (2000); Singh (2000); Utami \& Nahartyo (2013). Dengan demikian agar burnout dapat diturunkan disarankan pimpinan untuk menurunkan konflik peran khususnya pada tiga indikator yang dinilai paling tinggi yaitu bekerja dengan dua atau lebih 
kelompok secara berbeda; harus memuaskan terlalu banyak orang yang berbeda; dan mencoba untuk memenuhi tuntutan bertentangan dari berbagai departemen.

Uji hipotesis ketiga menunjukan bahwa burnout berpengaruh signifikan negatif terhadap komitmen. Hasil penelitian ini mendukung penelitian yang dilakukan oleh Babakus et al. (1999) yang menyatakan kelelahan emosional dalam dimensi burnout berpengaruh negatif terhadap komitmen organisasional. Salehi \& Gholtash (2011) menyatakan bahwa job burnout memiliki efek negatif terhadap komitmen organisasi. Agar komitmen meningkat disarankan untuk mengelola tiga indikator burnout yang dinilai tertinggi yaitu kelelahan karena memenuhi harapan; kecewa dengan tindakan; dan kurang simpatik.

Maslach et al. (2001) menyatakan burnout dipandang sebagai bentuk stres kerja, dengan tautan ke konsep kepuasan kerja, komitmen organisasi, dan turnover. Bagi orang yang bekerja kelelahan tidak bisa dihindari, namun kelelahan yang berlebihanlah yang menyebabkan produktivitas dan efektivitas kerja menjadi lebih rendah. Lebih lanjut hal ini dikaitkan dengan penurunan kepuasan kerja dan berkurangnya komitmen terhadap pekerjaan atau organisasi. Singh (2000) menyatakan bahwa burnout berpengaruh negatif terhadap komitmen. Leiter \& Maslach (1988) menunjukan bahwa pekerja yang berkomitmen berinteraksi lebih sering dengan pekerja lain yang berkomitmen, dan pekerja yang acuh tak acuh terhadap organisasi berinteraksi lebih sering dengan rekan kerja yang berpikiran sama. Hasilnya konsisten dengan yang dihipotesiskan bahwa burnout mengarah pada berkurangnya komitmen organisasi. Untuk itu organisasi atau perusahaan perlu mengatasi dan memperbaiki serta mencari solusi yang tepat dengan manajemen kelelahan yang baik agar dapat meningkatkan komitmen seseorang dalam berorganisasi.

Hasil uji hipotesis keempat menunjukkan terdapat pengaruh negatif signifikan ambiguitas peran terhadap komitmen. Hasil ini mendukung penelitian yang dilakukan oleh Han, Han, An, \& Lim (2014) bahwa ambiguitas peran mengurangi komitmen organisasi. Ambiguitas peran dapat menyebabkan ketidakpuasan kerja hingga kejenuhan yang mengakibatkan menurunnya komitmen organisasi (Saraswati, Atmadja, \& Darmawan, 2014). Pengaruh ambiguitas peran sangat besar, tidak hanya pada individu tapi juga berdampak pada perusahaan. Tethool (2013) dalam penelitiannya juga menunjukkan ada korelasi negatif antara ambiguitas peran terhadap komitmen organisasi.

Hipotesis kelima ditolak, ditemukan ada pengaruh positif konflik peran terhadap komitmen, temuan ini mendukung hasil penelitian (Sari, 2016). Responden dengan usia di atas 25 tahun sebanyak 88,3\% berpengaruh dalam memandang konflik, konflik tidak serta merta menurunkan komitmen kerja. Konflik peran yang dipersepsikan secara positif akan mendorong 
karyawan untuk dapat menangani konflik dengan menghasilkan resolusi konflik peran yang tepat sehingga akan menciptakan komitmen organisasional menjadi lebih baik. Sebanyak 50\% responden sudah berusia diatas 35 tahun diduga membuat mereka lebih memilih menjaga komitmen karena sudah mengenal perusahaannya daripada pindah meskipun mengalami konflik peran.

Hasil pengolahan uji mediasi hipotesis keenam dan ketujuh menggunakan Sobel test menunjukan burnout memediasi ambiguitas peran terhadap komitmen. Selanjutnya pengolahan uji mediasi ketujuh juga menunjukkan bahwa burnout memediasi konflik peran terhadap komitmen. Silvia (2017) juga meletakan burnout sebagai variabel mediasi, hasilnya stres kerja memediasi konflik peran dan ambiguitas peran terhadap komitmen organisasi. Temuan ini juga mengkonfirmasi model mediasi konstruk burnout Singh (2000) dan Han, Han, An, \& Lim (2014).

\section{SIMPULAN \& SARAN}

Temuan menunjukkan konflik peran berpengaruh positif terhadap burnout, menariknya ambiguitas justru ditemukan berpengaruh negatif terhadap burnout. Lebih lanjut ambiguitas peran dan burnout ditemukan secara parsial berpengaruh negatif terhadap komitmen, sementara konflik justru ditemukan berpengaruh positif terhadap komitmen. Pimpinan perusahaan disarankan untuk menurunkan implementasi indikator variabel konflik dan burnout yang dinilai tinggi seperti yang disebutkan di pembahasan. Penelitian kedepan perlu mengkaji lebih lanjut tambahan variabel lain seperti kepuasan kerja, dukungan organisasi, kecerdasan emosional dalam pengaruhnya terhadap komitmen.

\section{DAFTAR PUSTAKA}

Babakus, E., Cravens, D. W., Johnston, M., \& Moncrief, W. C. (1999). The Role of Emotional Exhaustion in Sales Force Attitude and Behavior Relationships. Journal of the Academy of Marketing Science, 27(1), 58-70. https://doi.org/10.1177/0092070399271005

Biddle, B. J. (1986). Recent Developments in Role Theory. Annual Review of Sociology, 12(1), 67-92. https://doi.org/10.1146/annurev.soc.12.1.67

Buchanan, B. (1974). Building Organizational Commitment: The Socialization of Managers in Work Organizations. Administrative Science Quarterly, 19(4), 533-546. https://doi.org/10.2307/2391809

Fisher, C. D., \& Gitelson, R. (1983). A Meta-Analysis of the Correlates of Role Conflict and Ambiguity. Journal of Applied Psychology, 68(2), 320-333. https://doi.org/10.1037/00219010.68.2.320

Fogarty, T., Singh, J., Rhoads, G., \& Moore, R. (2000). Antecedents and Consequences of Burnout in Accounting: Beyond the Role Stress Model. Behavioral Research in Accounting, 12(May 2014), 31-67.

Han, S., Han, J., An, Y., \& Lim, S. (2014). Effects of role stress on nurses ' turnover intentions: 
The mediating effects of organizational commitment and burnout. Japan Journal of Nursing Science, 12(4), 1-10. https://doi.org/10.1111/jjns.12067

Harms, P. D., \& Luthans, F. (2012). Measuring implicit psychological constructs in organizational behavior: An example using psychological capital. Journal of Organizational Behavior, 33(4), 589-594. https://doi.org/10.1002/job.1785

Ilgen, D. R., \& Hollenbeck, J. R. (1991). The Structure of Work : Job Design and Roles. In Handbook of industrial and organizational psychology. Amerika Serikat: Michigan State University.

Johnson, T. W., \& Stinson, J. E. (1975). Role ambiguity, Role Conflict, and Satisfaction: Moderating Effects of Individual Differences. Journal of Applied Psychology, 60(3), 329333. https://doi.org/10.1037/h0076752

Judeh, M. (2011). Role Ambiguity and Role Conflict as Mediators of the Relationship between Orientation and Organizational Commitment. International Business Research, 4(3), 171181. https://doi.org/10.5539/ibr.v4n3p171

Kahn, R. L., Wolfe, D. M., Quinn, R. P., \& Snoek, J. D., \& Rosenthal, R. A. (1964). Organizational Stress: Studies in role conflict and ambiguity.

Kim, H., \& Stoner, M. (2008). Burnout and turnover intention among social workers: Effects of role stress, job autonomy and social support. Administration in Social Work, 32(3), 5 25. https://doi.org/10.1080/03643100801922357

Kurniawan, I. S., \& Tamrin, H. (2019). Faktor yang Mempengaruhi Turnover Intention Pramuniaga. Jurnal Ilmiah Ekonomi Dan Bisnis, 16(2), 158-167. https://doi.org/https://doi.org/10.31849/jieb.v16i2.2935

Lee, R. T., \& Ashforth, B. E. (1996). A Meta-Analytic Examination of the Correlates of the Three Dimensions of Job Burnout. Journal of Applied Psychology, 81(2), 123-133. https://doi.org/10.1037/0021-9010.81.2.123

Leiter, M. P., \& Maslach, C. (1988). The impact of interpersonal environment on burnout and organizational commitment. Journal of Organizational Behavior, 9(4), 297-308. https://doi.org/10.1002/job.4030090402

Lloyd, C., King, R., \& Chenoweth, L. (2002). Social work, stress and burnout: A review. Journal of Mental Health, 11(3), 255-265. https://doi.org/10.1080/09638230020023642

Maslach, C., Schaufeli, W. B., \& Leiter, M. P. (2001). Job Burnout. Annual Review of Psychology, 52(1), 397-422. https://doi.org/10.1146/annurev.psych.52.1.397

Neckel, S., Schaffner, A. K., \& Wagner, G. (2017). Burnout, Fatigue, Exhaustion. In This Palgrave Macmillan. Cham: Springer.

Ogston, S. A., Lemeshow, S., Hosmer, D. W., Klar, J., \& Lwanga, S. K. (1991). Adequacy of Sample Size in Health Studies. In World Health Organization (p. 347). https://doi.org/10.2307/2532527

Porter, L. W., Steers, R. M., \& Boulian, P. V. (1973). Organizational commitment, job satisfaction, and turnover among psychiatric technicians. Journal of Applied Psychology, 59(5), 1-21. Retrieved from https://files.eric.ed.gov/fulltext/ED099485.pdf

Rizzo, J. R., House, R. J., \& Lirtzman, S. I. (1970). Role Conflict and Ambiguity in Complex Organizations. Administrative Science Quarterly, 15(2), 150-163. https://doi.org/10.2307/2391486

Salehi, M., \& Gholtash, A. (2011). The relationship between job satisfaction, job burnout and organizational commitment with the organizational citizenship behavior among members of faculty in the Islamic Azad University-first district branches, in order to provide the appropriate model. Procedia - Social and Behavioral Sciences, 15(April 2016), 306-310. https://doi.org/10.1016/j.sbspro.2011.03.091

Saraswati, N. P. I. P., Atmadja, A. T., \& Darmawan, N. A. S. (2014). Pengaruh Tekanan Klien, Konflik Peran dan Role Ambiguity Terhadap Komitment Independensi Aparat Inspektorat Pemerintah Daerah (Studi Empiris Pada Inspektorat Kota Denpasar dan Kabupaten

Mediasi Burnout Pada Pengaruh.... 
Gianyar). E-Journal S1 Ak Universitas Pendidikan Ganesha Jurusan Akuntansi Program S1, 2(1). https://doi.org/http://dx.doi.org/10.23887/jimat.v2i1.2977

Sari, F. (2016). Pengaruh Servant Leadership, Konflik Peran dan Komitmen Organisasional Terhadap Organizational Citizenship Behavior (Studi pada Bappeda Kabupaten Rembang). Retrieved from http://eprints.undip.ac.id/50112/

Silvia, C. . A. Y. (2017). Analisis Pengaruh Konflik peran dan Ambiguitas Peran Terhadap Komitmen Organisasi Melalui Stres Kerja Sebagai variabel Intervening (Studi Pada Karyawan PT. Telekomunikasi Indonesia,TBK. Witel Semarang). Diponegoro Journal Of Management, 6(4), 1-15.

Singh, J. (2000). Performance Productivity and Quality of Frontline Employees in Service $\begin{array}{llll}\text { Organizations. Journal of } & \text { 15-34. }\end{array}$ https://doi.org/https://doi.org/10.1509/jmkg.64.2.15.17998

Tethool, N. A. (2013). Pengaruh Konflik Peran dan Ambuguitas Peran terhadap Komitmen Organisasional dan Kepuasan Kerja sebagai Variabel Moderator di Regional Tengah (Jogja dan Solo). In Jurnal Ilmiah Manajemen. Retrieved from http://ejournal.uajy.ac.id/4737/

Utami, I., \& Nahartyo, E. (2013). The Effect of Type a Personality on Auditor Burnout: Evidence from Indonesia. Accounting and Taxation, 5(2), 89-103.

Wu, G., Hu, Z., \& Zheng, J. (2019). Role stress, job burnout, and job performance in construction project managers: The moderating role of career calling. International Journal of Environmental Research and Public Health, 16(13). https://doi.org/10.3390/ijerph16132394

Yener, D., Oskaybas, K., \& Dursun, T. (2014). The Effects of Burnout on Organizational Commitment in Logistics Sector. Journal of Business Research - Turk, 6(2), 15-25. https://doi.org/10.20491/isader.2014215951

Zeng, S. X., Meng, X. H., Zeng, R. C., Tam, C. M., Tam, V. W. Y., \& Jin, T. (2011). How environmental management driving forces affect environmental and economic performance of SMEs: A study in the Northern China district. Journal of Cleaner Production, 19(13), 1426-1437. https://doi.org/10.1016/j.jclepro.2011.05.002

Zhaleh, K., Ghonsooly, B., \& Pishghadam, R. (2018). Effects of conceptions of intelligence and ambiguity tolerance on teacher burnout: A case of Iranian EFL teachers. Journal of Research in Applied Linguistics, 9(2), 118-140. https://doi.org/10.22055/rals.2018.13796 